Chimia 45 (1991) 322-324

(C) Schweiz. Chemiker-Verband; ISSN 0009-4293

\title{
Solvatochromic Dyes as Empirical Indicators of Solvent Polarity
}

\author{
Christian Reichardt*
}

As every chemist knows, solvents can have a strong influence on reaction rates, on the position of chemical equilibria, and on the position of spectral absorption bands [1] $E . g$. , the $S_{\mathrm{N}}$ l solvolysis of 2-chloro-2-methylpropane is $c a .10^{11}$ times faster in water than in the less polar solvent benzene. Chemists have usually attempted to understand solvent effects in terms of the polarity of the solvent. But what does solvent polarity mean? The simplicity of idealized electrostatic solvation models has led to the use of the relative permittivity $\left(\varepsilon_{\mathrm{r}}\right)$ and of the permanent dipole moment $(\mu)$ - or functions thereof - as solvent polarity parameters. This approach often failed because the intermolecular forces between solute and solvent molecules are much more complicated: in addition to the nonspecific coulombic, directional, inductive, and dispersion interactions, there exist also specific interactions such as hydrogen bonding, electron-pair donor (EPD)/electron-pair acceptor (EPA), and solvophobic interactions. Hence, from a more practical point of view, it seems to be more favourable to include in the term 'solvent polarity' the overall solvation capability for $i$ ) educts and products ( $\rightarrow$ chemical equilibria), ii) reactants and activated complexes ( $\rightarrow$ reaction rates), and $i i i$ ) molecules in the ground and excited state $(\rightarrow$ light absorption), which in turn depends on the action of all possible, nonspecific and specific, intermolecular interactions between solute and solvent molecules - excluding such interactions leading to definite chemical alterations of the solute molecules [2].

Obviously, solvent polarity such defined cannot be described quantitatively by means of single physical parameters such as permittivity or dipole moment. Other indices of solvent polarity are sought. Therefore, empirical parameters of solvent polarity have been introduced [1]. A common approach is to assume that some particular equilibrium, reaction rate, or spectral absorption is a suitable model for other solvent-dependent processes. If one carefully selects an appropriate, sufficiently solvent-sensitive reference process, an empirical measure of solvent polarity can be derived from it, which is believed to provide a more comprehensive measure of the overall solvation capability of the solvents than do their individual physical data.

The first suggestion that solvatochromic dyes should be used as indicators of solvent polarity was made by Brooker et al. in 1951 [3], but Kosower in 1958 [4] was the first to set up an empirical solvent scale, using the intermolecular charge-transfer absorption of negatively solvatochromic l-ethyl-4-methoxycarbonylpyridinium iodide as a reference process. Kosower's Z-scale, although widely used, has some practical limitations. Therefore, in 1963, another solvent polarity scale, the so-called $E_{\mathrm{T}}(30)$-scale, has been introduced [5-7]. The negatively solvatochromic pyridinium $N$-phenoxide betaine dye 1 (see the Scheme) exhibits one of the largest solvatochromic effects ever observed: its long-wavelength intramolecular chargetransfer (CT) absorption band is shifted by $9730 \mathrm{~cm}^{-1}(357 \mathrm{~nm})$ on going from water $(\lambda$ $=453 \mathrm{~nm})$ to diphenyl ether $(\lambda=810 \mathrm{~nm})$. Solutions of 1 are red-coloured in methanol, violet in ethanol, blue in isoamyl alcohol, green in acetone, and yellow in anisole, thus comprising the whole visible region and allowing even a visual estimation of the solvent polarity.
The following peculiar properties of $\mathbf{1}$ are responsible for the solvent-mediated stabilization of its highly dipolar electronic ground state, relative to its less dipolar excited state: $i$ ) it exhibits a large permanent dipole moment, suitable for the registration of dipole/dipole and dipole/induced dipole interactions; ii) it possesses a large polarizable $\pi$-electron system, suitable for the registration of dispersion interactions; and iii) with the phenoxide oxygen atom it exhibits a highly basic electron-pair donor centre, suitable for interactions with Br $\phi n s t e d$ acids (H-bonding) and Lewis acids (EPD/EPA bonding). The positive charge of the pyridinium moiety is delocalized and sterically shielded. Therefore, the CT absorption of 1 depends strongly on the electrophilic solvation power of the solvents, i.e. on their HBD ability and Lewis acidity (= EPA behaviour), rather than on their nucleophilic solvation capability (= EPD behaviour).

$E_{\mathrm{T}}(30)$-values are simply defined as molar transition energies of 1 , measured in $\mathrm{kcal} / \mathrm{mol}$ (see the Scheme) [8]. A high $E_{\mathrm{T}}(30)-$ value corresponds to high solvent polarity. In order to avoid the dimension $\mathrm{kcal} / \mathrm{mol}$, the use of normalized $E_{\mathrm{T}}^{\mathrm{N}}$-values has been recommended recently [6]. They are defined according to Eqn. 1, using water and tetramethylsilane (TMS) as extreme reference solvents.

$$
E_{\mathrm{T}}^{\mathrm{N}}=\frac{E_{\mathrm{T}}(\text { solvent })-E_{\mathrm{T}}(\mathrm{TMS})}{E_{\mathrm{T}}(\text { water })-E_{\mathrm{T}}(\mathrm{TMS})}=\frac{E_{\mathrm{T}}(\text { solvent })-30.7}{32.4}(1)
$$

Hence, the $E_{\mathrm{T}}^{\mathrm{N}}$-scale ranges from 0.0 for TMS, the least polar solvent, to 1.0 for water, the most polar solvent.

Since betaine 1 is only sparingly soluble in water and insoluble in aliphatic hydrocarbons, the more lipophilic penta(tertbutyl)-substituted dye 2 [6] as well as the more hydrophilic methanesulfonyl-substituted dye 3 [9] have been used as secondary standard betaine dyes. That way, at present $E_{\mathrm{T}}(30)$-values are known for more than 300 organic solvents and numerous binary solvent mixtures [1][7].

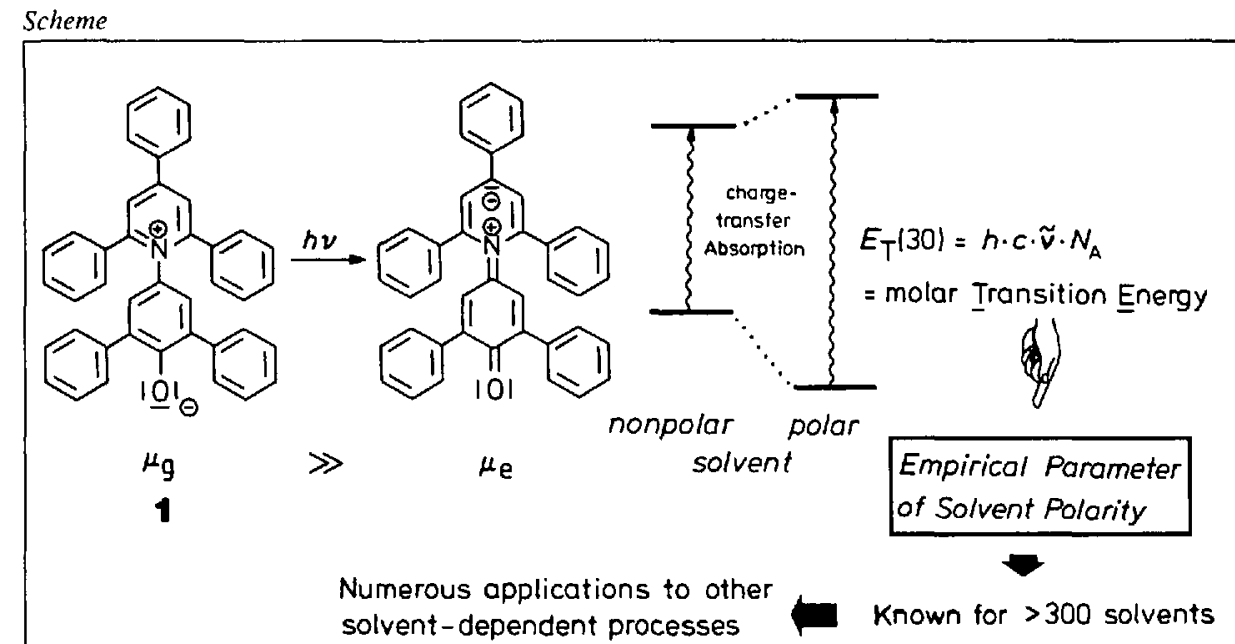

* Correspondence: Prof. Dr. Chr. Reichardt Fachbereich Chemic der Philipps-Universität Hans-Meerwein-Strasse

D-3550 Marburg 


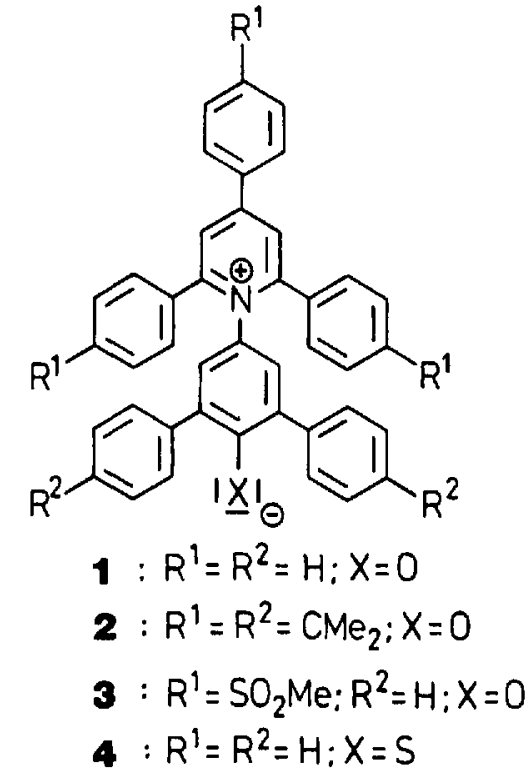

Surprisingly, the pyridinium $N$-thiophenoxide betaine dye 4 exhibits practically the same sensitivity to HBD (protic) solvents as $\mathbf{1}$, in spite of the fact that sulfur is known to act as worse $\mathrm{H}$-bond acceptor than oxygen [10].

The empirical solvent polarity parameter $E_{\mathrm{T}}(30)$ has found manifold applications some of which are compiled in the Figure. The application of the $E_{\mathrm{T}}(30)$-values to chemical reactivity [11] and analytical chemistry [12] has been reviewed.
In addition to its negative solvatochromism, pyridinium $N$-phenoxide betaine dyes such as 1 exhibit also the phenomenon of thermo-solvatochromism, piezo-solvatochromism, and halochromism [1]. That is, the position of the long-wavelength CTabsorption band of dissolved 1 depends on the solution temperature [13], on external pressure [14], and on the addition of salts (electrolytes; ionophores) [9][15]. Attempts at the discovery of so-called chiro-solvatochromism by means of the chiral $(S, S)$ configurated betaine dye 5 , dissolved in pairs of homochiral, enantiomeric solvents have failed so far [16].

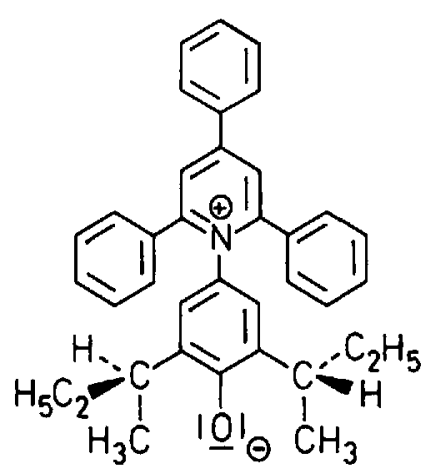

A decrease in the temperature of solutions of 1 leads to a hypsochromic shift of its CT-absorption band. This new kind of thermochromism, called thermo-solvatochromism, is obviously caused by increased solvent-mediated stabilization of the dipolar ground state of 1 relative to its less dipolar excited state. In other words, the lower the temperature, the higher the $E_{\mathrm{T}}(30)$-value of the solvent, and the higher its solvation capability. That is, solvent polarity is temperature-dependent [13].

With increasing external pressure (up to $10 \mathrm{kbar}$ ), again a hypsochromic shift in the solution spectra of $\mathbf{1}$ is observed [14]. This<smiles></smiles>

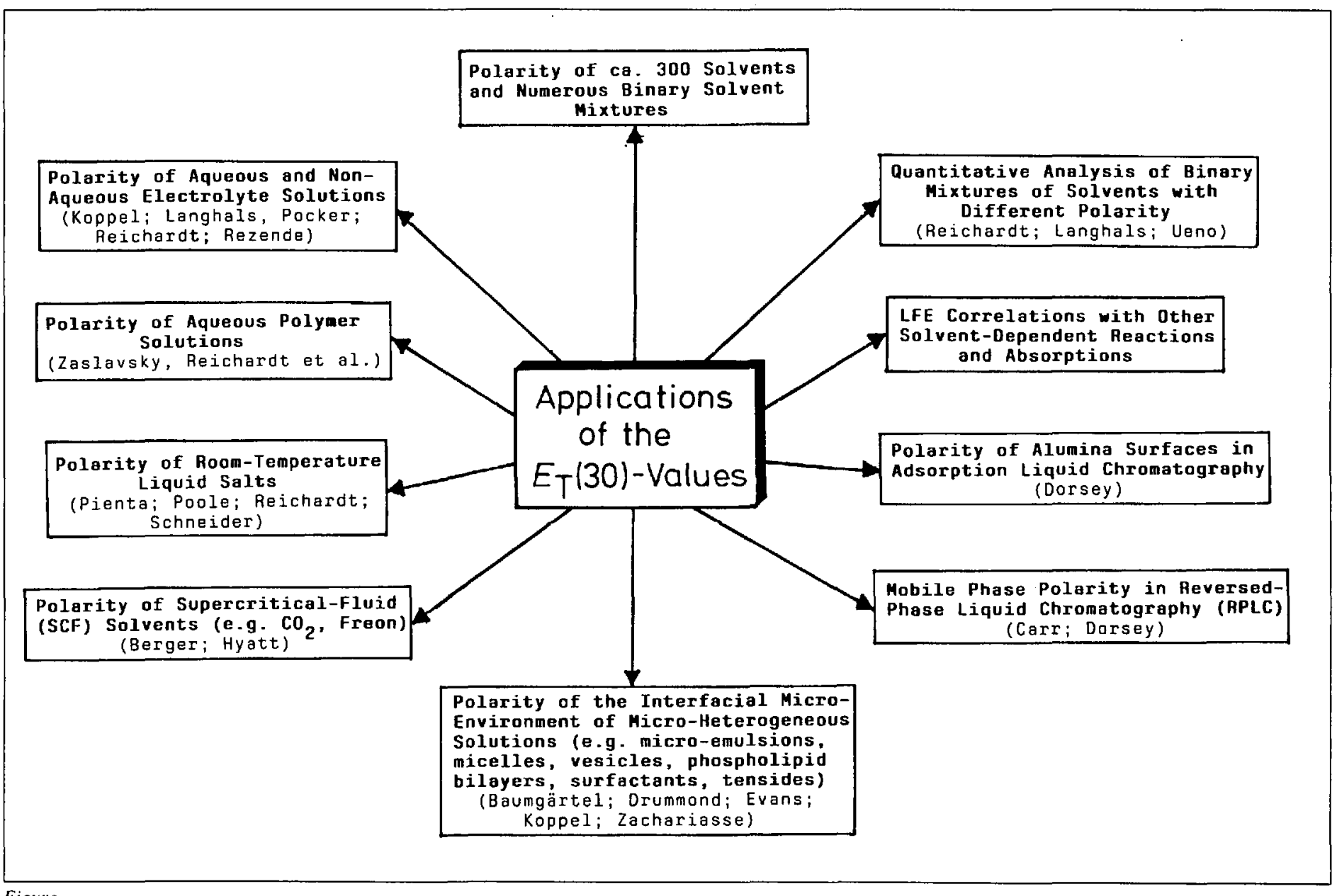


piezo-solvatochromism obviously results from the pressure-supported differential solvation of the dipolar ground state of 1 . The higher the external pressure, the higher the $E_{\mathrm{T}}(30)$-value of the solvent, and the higher its solvation capability. That is, solvent polarity is pressure-dependent. This pressuredependence of the solvation capability of organic solvents should not be neglected in modern high-pressure chemistry!

The addition of salts to solutions of $\mathbf{1}$ in organic solvents causes hypsochromic shifts of its solvatochromic CT-absorption band. E.g., the addition of $\mathrm{KI}, \mathrm{NaI}, \mathrm{LiI}, \mathrm{BaI}_{2}$, $\mathrm{Ca}(\mathrm{SCN})_{2}$, and $\mathrm{Mg}\left(\mathrm{ClO}_{4}\right)_{2}$ to solutions of 1 in acetonitrile leads to a differential hypsochromic band shift with this ionophore order, i.e. with increasing charge density of the cation [15]. The hypsochromic shifts are concentration-dependent, they increase with increasing salt concentration. Obviously, loose ion-pair formation between the phenoxide oxygen atom and the metal cation increases the ionization energy of the electron-donor moiety of $\mathbf{1}$, whereas the electron-acceptor part of 1 remains unchanged. As result, the intramolecular CT-absorption band of $\mathbf{1}$ is hypsochromically shifted.

Are aqueous electrolyte solutions more polar than pure water? Addition of salts (up to $1 \mathrm{~m}$ salt) to aqueous solutions of the more water-soluble betaine dye 3 leads in all cases to hypsochromic band shifts which correspond to an increase of the $E_{\mathrm{T}}(30)$-values by ca. $1-4 \mathrm{kcal} / \mathrm{mol}$ Thus, aqueous salt solutions are indeed more polar than water [9]. Unfortunately, $E_{\mathrm{T}}(30)$-values for higher concentrated aqueous salt solutions $(>1 \mathrm{M})$ are not available because the betaine dye 3 is salted out.

The salt-dependent solution spectra of 1 and 3 constitute a new type of genuine halo- chromism, in contrast to the trivial halochromism first found by Baeyer and Villiger [17]. Examples of this trivial halochromism are acid/base reactions in solution in which a colourless educt forms a coloured product during a chemical reaction, e.g. $\left(\mathrm{C}_{6} \mathrm{H}_{5}\right)_{3} \mathrm{C}$ $\mathrm{OH}$ (colourless) $+\mathrm{H}_{3} \mathrm{O}^{+} \rightarrow\left(\mathrm{C}_{6} \mathrm{H}_{5}\right)_{3} \mathrm{C}^{+}$ (yellow) $+2 \mathrm{H}_{2} \mathrm{O}$. The genuine halochromism of $\mathbf{1}$ and 3, however, is produced without any chemical alteration of the halochromic dyes! We have recently proposed to speak of negative (positive) genuine halochromism then only when the UV/VIS-absorption band of a dissolved compound is hypsochromically (bathochromically) shifted on addition of an added electrolyte, and when this band shift is not accompanied by a chemical alteration of the chromophore [9][18].

A particular cation-selective genuine halochromism has been observed in solutions of the new crown-ether substituted betaine dyes 6 [18]. E.g., addition of $10^{-2} \mathrm{M}$ potassium iodide to a $10^{-3} \mathrm{M}$ solution of $6(n=1)$ in acetonitrile gives rise to a colour change from violet $(\lambda=583 \mathrm{~nm})$ to dark-red $(\lambda=529$ $\mathrm{nm} ; \Delta \lambda=-54 \mathrm{~nm})$. Again, an ion-pair formation between alkali metal cation and phenoxide part, supported by the crown-ether ring, is responsible for this rather large halochromic shift of the intramolecular CT band of 6. Since this negative halochromism depends on the radius of the cation of the added salt as well as on the size of the crown-ether ring, the new betaine dyes 6 represent a new class of cation-selective chromoionophores possibly useful as cation indicators.

I thank all my coworkers listed in the references This work was supported by the Deutsche Forschungsgemeinschaft, Bonn, and the Fonds der Chemischen Industrie, Frankfurt (Main).
[1] C. Reichardt, 'Solvents and Solvent Effects in Organic Chemistry', 2nd revised and enlarged edn., VCH Verlagsgesellschaft, Weinheim, 1988.

[2] C. Reichardt, Angew. Chem. 1965, 77, 30; ibid. Int. Ed. 1965, 4, 29.

[3] L. G.S. Brooker, G. H. Keyes, D. W. Heseltine, J. Am. Chem. Soc. 1951, 73, 5350.

[4] E. M. Kosower,J.Am.Chem.Soc. 1958, 80, 3253.

[5] K. Dimroth, C. Reichardt, T. Siepmann, F. Bohlmann, Liebigs Ann. Chem. 1963, 66I, I.

[6] C. Reichardt, E. Harbusch-Görnert, Liebigs Amm. Chem. 1983, 721 .

[7] Latest publication (Part XVI) in the series 'Pyridinium $N$-phenoxide Betaines and Their Application for the Characterization of Solvent Polarities': S. Spange, M. Lauterbach, A.-K. Gyra, C. Reichardt, Liebigs Ann. Chem. 1991, 323.

[8] In the first publication of this series [5], betaine dye 1 had by chance the formula number 30 . Therefore, the number $\mathbf{3 0}$ was added in order to avoid confusion with $E_{\mathrm{T}}$ used in photochemistry as abbreviation for triplel energy.

[9] C.Reichardt, G.Schüfer, P. Milart, Collect.Czech. Chem. Commun. 1990, 55, 97.

[10] C. Reichardt, M. Eschner, Liebigs Amn. Chem., in press.

[11] C. Reichardt, Pure Appl. Chem. 1982, 54, 1867.

[12] B. P. Johnson, B. Gabrielsen, M. Matulenko, J. G. Dorsey, C. Reichardt, Anal. Letl. 1986, 19, 939.

[13] R. I. Zalewski, I. Adamczewska, C. Reichardt, $J$. Chem. Res. (S) 1990, 280; ibid. (M) 1990, 2157.

[14] W.S. Hammack, D. N. Hendrickson, H. G. Drickamer, J. Phys. Chem. 1989, 93, 3483.

[15] G. Hollmann, F. Vögtle, Chem. Ber. 1984, 1/7, 1355.

[16] C. Reichardt, M. Wilk, Liebigs Ann. Chem. 1990 , 189; C. Reichardt, S. Asharin-Fard, unpublished results.

[17] A. Baeyer, V. Villiger, Ber. Disch. Chem. Ges. 1902, 35, 1189

[18] C. Reichardt, S. Asharin-Fard, Angew. Chem 1991, 103, 614; ibid. Int. Ed. 1991, 30, 558. 
Schweizerischer Chemiker-Verband

Schweizerische Chemische Gesellschaft

Association Suisse des Chimistes

Société Suisse de Chimie

Swiss Association of Chemists

Swiss Chemical Society

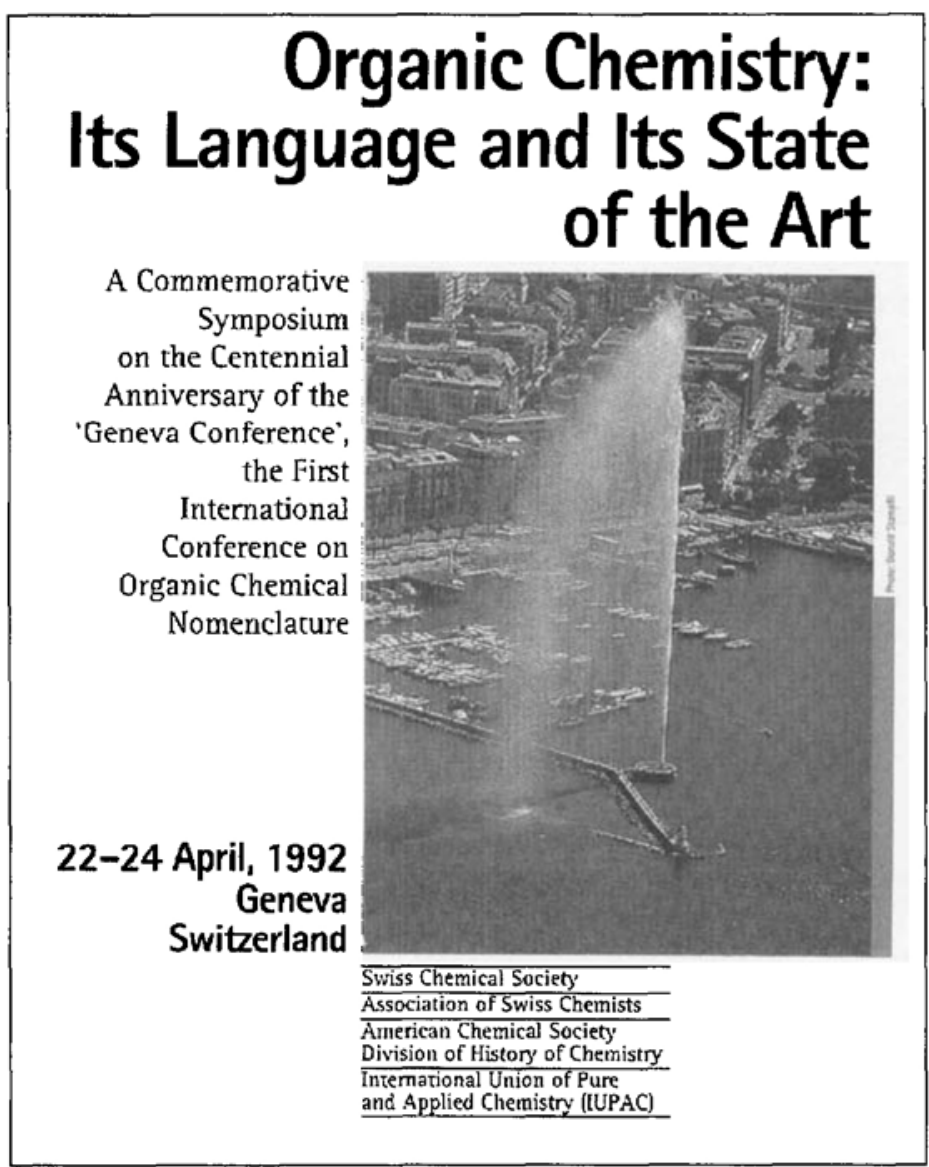

For further information, contact the Conference Chairman:

Dr. M. Volkan Kisakürek

Editor, Helvetica Chimica Acta

Postfach 313

CH-4010 Basel, Switzerland

\section{Schweizerischer Chemiker-Verband \\ Schweizerische Chemische Gesellschaft \\ Association Suisse des Chimistes \\ Société Suisse de Chimie \\ Swiss Association of Chemists \\ Swiss Chemical Society}

Preannouncement

6th International Seminar on

\section{Modern Synthetic Methods}

May 4/5, 1992, Interlaken, Switzerland

Chairman: Prof. Rolf Scheffold, University of Bern

Topics in Carbanion Chemistry

Topics in Carbohydrate Chemistry

The detailed programme will be available in Dezember 1991:

Secretary's Office for Symposia

c/o Institute of Organic Chemistry University of Bern

Freiestrasse 3

CH-3012 Bern

Tel. 0316543 11, Fax 031654499

\section{Vorträge}

Polymer-Gruppe der Schweiz

Groupe Suisse des Polymères

Gruppo Svizzero dei Polimeri

29. November 1991 'Polymers for High Technology'

(Réunion Annuelle/Jahrestagung der Polymer Gruppe der Schweiz)

Anmeldung und nähere Auskünfte

Frau S. Read

Sekretariat PGS

Institut für Polymere, ETH-Zentrum

Universitätstrasse 6

CH-8092 Zürich

Tel.: 012563058

30. November $1991 \quad$ Special Polymer Colloquium

'Structure, Deformation and Fracture of Polymers'

Anmeldung und nähere Auskünfte

Mme A. Marciano

EPFL-MX-G

Laboratoire de Technologie des Composites et Polymères

CH-1015 Lausanne

Tél.: 0216934285

\section{Chemische Gesellschaft Fribourg}

Die Vorträge finden jeweils im grossen Hörsaal der Chemischen Institute der Universität Fribourg (Pérolles) statt.

\section{November 199}

17.15 Uhr

19. November 1991

17.15 Uhr
Prof. Dr. P. Müller

Université de Genève

'Chemistry of Cyclopropenes and Cycloproparenes - Synthetic and Mechanistic Studies on Strain and Aromaticity'

Prof. Dr. H. Berke

Universität Zürich

'How to Make Transition Metal Hydrogen Bonds More Reactive - a Conceptual Approach'

\section{Synopsis}

\section{Nomenclature and terminology of graphite intercalation} compounds

Covalent graphite compounds, i.e. graphite fluoride and graphite oxide, should be distinguished from graphite intercalation compounds in which layers of the intercalated substance are inserted between planar carbon sheets of the graphite structure with concomitant charge transfer. Particular to graphite inter- calation compounds is their tendency to form periodically stacked highstage compounds in which only a fraction of the interlayer spaces of the graphite host lattice is filled with intercalated layers. The stage number is defined by the ratio of the total number of interlayer spaces to the number of filled interlayer spaces. 
Schweizerischer Chemiker-Verband

Schweizerische Chemische Gesellschaft

Association Suisse des Chimistes

Société Suisse de Chimie

Swiss Association of Chemists

Swiss Chemical Society

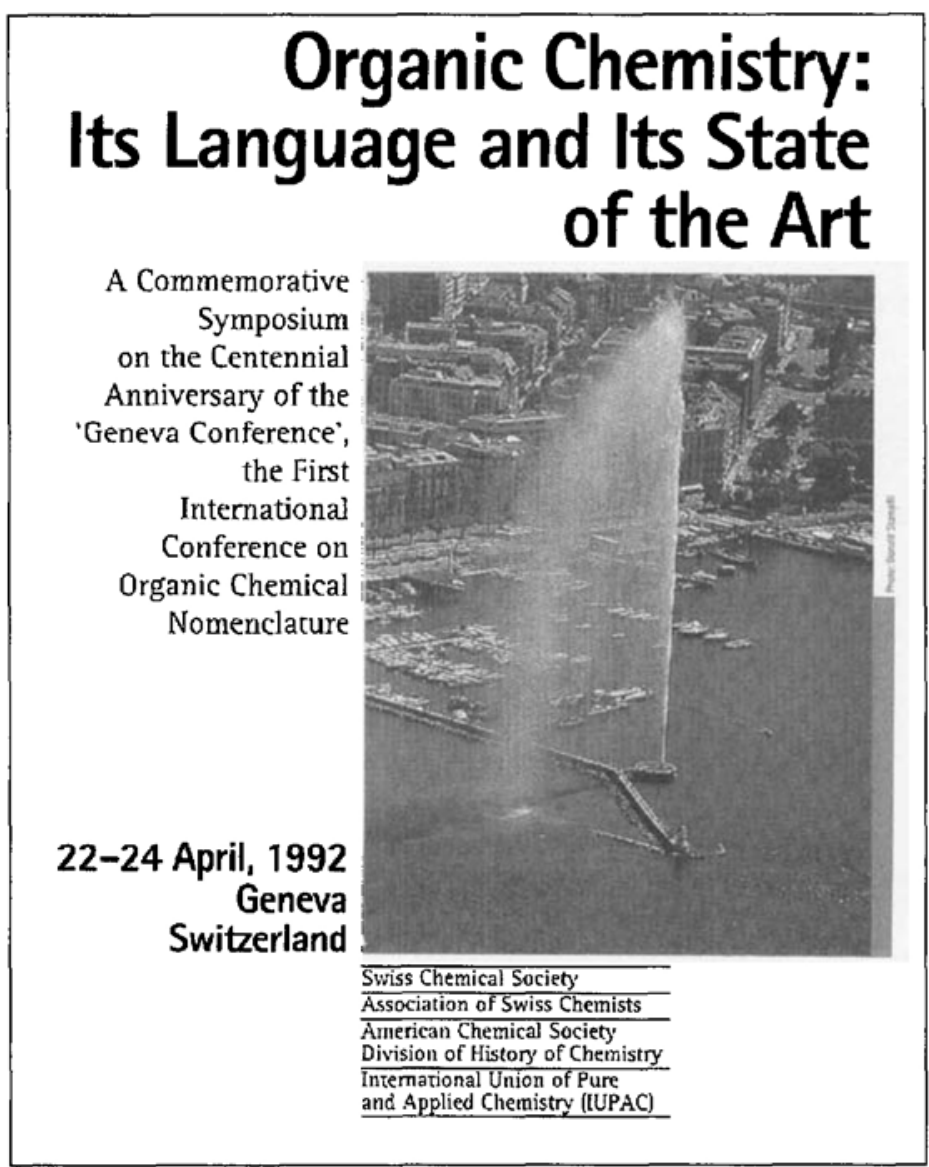

For further information, contact the Conference Chairman:

Dr. M. Volkan Kisakürek

Editor, Helvetica Chimica Acta

Postfach 313

CH-4010 Basel, Switzerland

\section{Schweizerischer Chemiker-Verband \\ Schweizerische Chemische Gesellschaft \\ Association Suisse des Chimistes \\ Société Suisse de Chimie \\ Swiss Association of Chemists \\ Swiss Chemical Society}

Preannouncement

6th International Seminar on

\section{Modern Synthetic Methods}

May 4/5, 1992, Interlaken, Switzerland

Chairman: Prof. Rolf Scheffold, University of Bern

Topics in Carbanion Chemistry

Topics in Carbohydrate Chemistry

The detailed programme will be available in Dezember 1991:

Secretary's Office for Symposia

c/o Institute of Organic Chemistry University of Bern

Freiestrasse 3

CH-3012 Bern

Tel. 0316543 11, Fax 031654499

\section{Vorträge}

Polymer-Gruppe der Schweiz

Groupe Suisse des Polymères

Gruppo Svizzero dei Polimeri

29. November 1991 'Polymers for High Technology'

(Réunion Annuelle/Jahrestagung der Polymer Gruppe der Schweiz)

Anmeldung und nähere Auskünfte

Frau S. Read

Sekretariat PGS

Institut für Polymere, ETH-Zentrum

Universitätstrasse 6

CH-8092 Zürich

Tel.: 012563058

30. November $1991 \quad$ Special Polymer Colloquium

'Structure, Deformation and Fracture of Polymers'

Anmeldung und nähere Auskünfte

Mme A. Marciano

EPFL-MX-G

Laboratoire de Technologie des Composites et Polymères

CH-1015 Lausanne

Tél.: 0216934285

\section{Chemische Gesellschaft Fribourg}

Die Vorträge finden jeweils im grossen Hörsaal der Chemischen Institute der Universität Fribourg (Pérolles) statt.

\section{November 199}

17.15 Uhr

19. November 1991

17.15 Uhr
Prof. Dr. P. Müller

Université de Genève

'Chemistry of Cyclopropenes and Cycloproparenes - Synthetic and Mechanistic Studies on Strain and Aromaticity'

Prof. Dr. H. Berke

Universität Zürich

'How to Make Transition Metal Hydrogen Bonds More Reactive - a Conceptual Approach'

\section{Synopsis}

\section{Nomenclature and terminology of graphite intercalation} compounds

Covalent graphite compounds, i.e. graphite fluoride and graphite oxide, should be distinguished from graphite intercalation compounds in which layers of the intercalated substance are inserted between planar carbon sheets of the graphite structure with concomitant charge transfer. Particular to graphite inter- calation compounds is their tendency to form periodically stacked highstage compounds in which only a fraction of the interlayer spaces of the graphite host lattice is filled with intercalated layers. The stage number is defined by the ratio of the total number of interlayer spaces to the number of filled interlayer spaces. 
Schweizerischer Chemiker-Verband

Schweizerische Chemische Gesellschaft

Association Suisse des Chimistes

Société Suisse de Chimie

Swiss Association of Chemists

Swiss Chemical Society

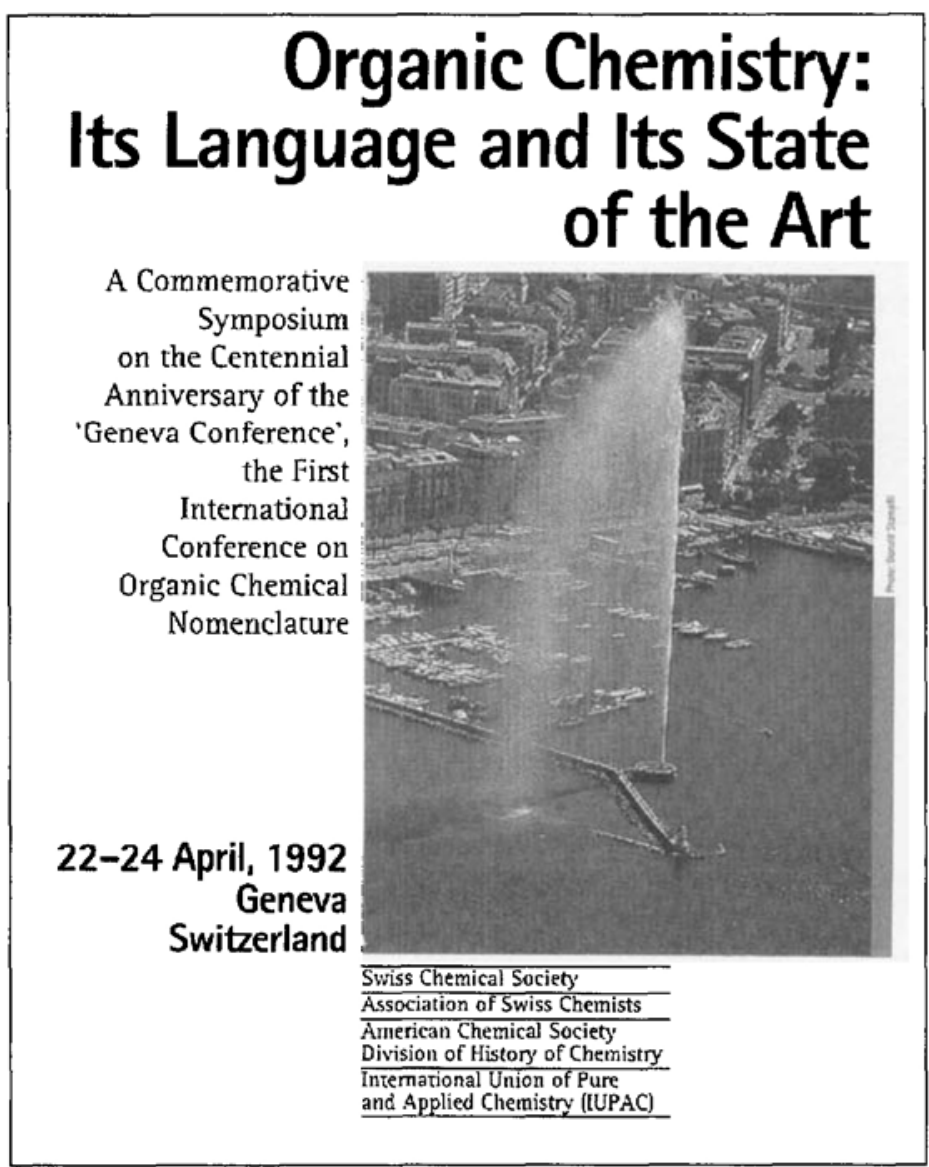

For further information, contact the Conference Chairman:

Dr. M. Volkan Kisakürek

Editor, Helvetica Chimica Acta

Postfach 313

CH-4010 Basel, Switzerland

\section{Schweizerischer Chemiker-Verband \\ Schweizerische Chemische Gesellschaft \\ Association Suisse des Chimistes \\ Société Suisse de Chimie \\ Swiss Association of Chemists \\ Swiss Chemical Society}

Preannouncement

6th International Seminar on

\section{Modern Synthetic Methods}

May 4/5, 1992, Interlaken, Switzerland

Chairman: Prof. Rolf Scheffold, University of Bern

Topics in Carbanion Chemistry

Topics in Carbohydrate Chemistry

The detailed programme will be available in Dezember 1991:

Secretary's Office for Symposia

c/o Institute of Organic Chemistry University of Bern

Freiestrasse 3

CH-3012 Bern

Tel. 0316543 11, Fax 031654499

\section{Vorträge}

Polymer-Gruppe der Schweiz

Groupe Suisse des Polymères

Gruppo Svizzero dei Polimeri

29. November 1991 'Polymers for High Technology'

(Réunion Annuelle/Jahrestagung der Polymer Gruppe der Schweiz)

Anmeldung und nähere Auskünfte

Frau S. Read

Sekretariat PGS

Institut für Polymere, ETH-Zentrum

Universitätstrasse 6

CH-8092 Zürich

Tel.: 012563058

30. November $1991 \quad$ Special Polymer Colloquium

'Structure, Deformation and Fracture of Polymers'

Anmeldung und nähere Auskünfte

Mme A. Marciano

EPFL-MX-G

Laboratoire de Technologie des Composites et Polymères

CH-1015 Lausanne

Tél.: 0216934285

\section{Chemische Gesellschaft Fribourg}

Die Vorträge finden jeweils im grossen Hörsaal der Chemischen Institute der Universität Fribourg (Pérolles) statt.

\section{November 199}

17.15 Uhr

19. November 1991

17.15 Uhr
Prof. Dr. P. Müller

Université de Genève

'Chemistry of Cyclopropenes and Cycloproparenes - Synthetic and Mechanistic Studies on Strain and Aromaticity'

Prof. Dr. H. Berke

Universität Zürich

'How to Make Transition Metal Hydrogen Bonds More Reactive - a Conceptual Approach'

\section{Synopsis}

\section{Nomenclature and terminology of graphite intercalation} compounds

Covalent graphite compounds, i.e. graphite fluoride and graphite oxide, should be distinguished from graphite intercalation compounds in which layers of the intercalated substance are inserted between planar carbon sheets of the graphite structure with concomitant charge transfer. Particular to graphite inter- calation compounds is their tendency to form periodically stacked highstage compounds in which only a fraction of the interlayer spaces of the graphite host lattice is filled with intercalated layers. The stage number is defined by the ratio of the total number of interlayer spaces to the number of filled interlayer spaces. 
Schweizerischer Chemiker-Verband

Schweizerische Chemische Gesellschaft

Association Suisse des Chimistes

Société Suisse de Chimie

Swiss Association of Chemists

Swiss Chemical Society

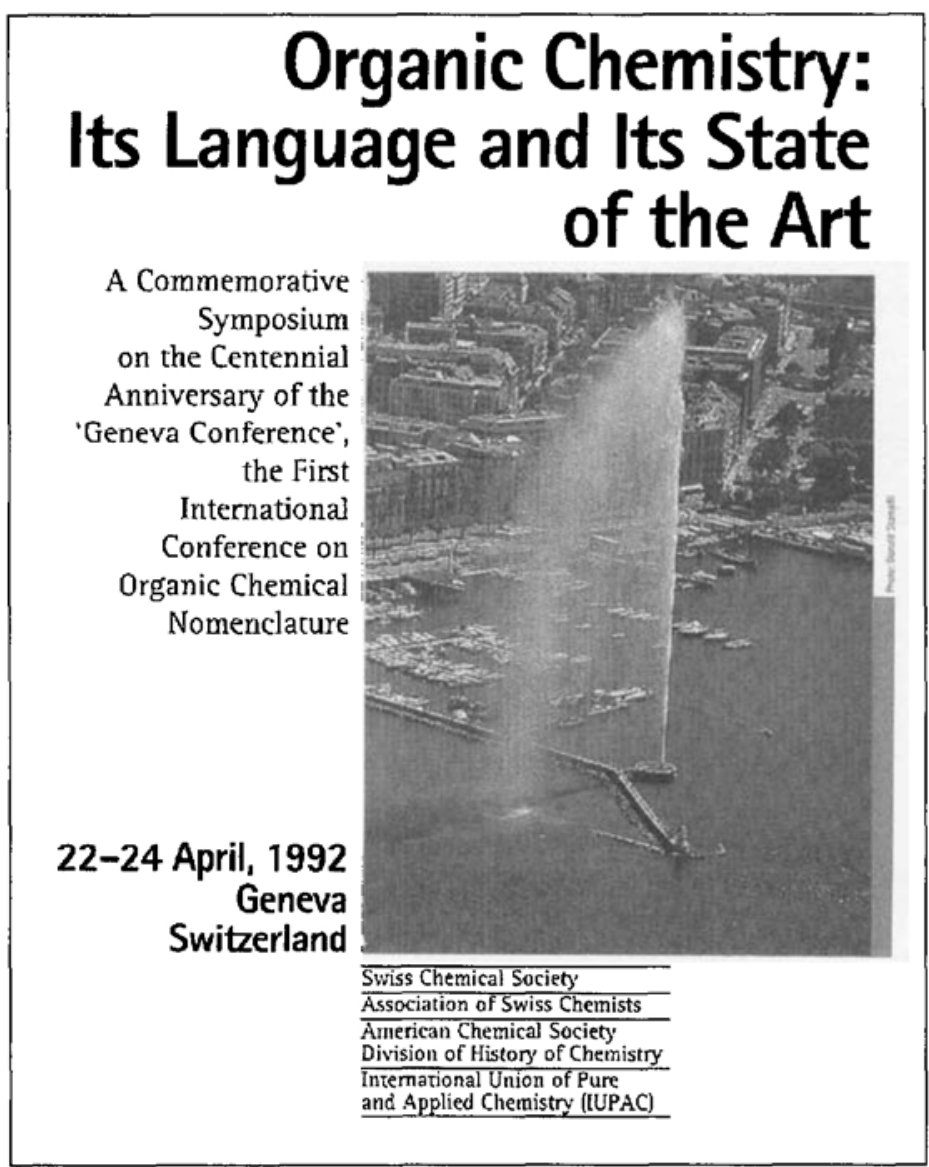

For further information, contact the Conference Chairman:

Dr. M. Volkan Kisakürek

Editor, Helvetica Chimica Acta

Postfach 313

CH-4010 Basel, Switzerland

\section{Schweizerischer Chemiker-Verband \\ Schweizerische Chemische Gesellschaft \\ Association Suisse des Chimistes \\ Société Suisse de Chimie \\ Swiss Association of Chemists \\ Swiss Chemical Society}

Preannouncement

6th International Seminar on

\section{Modern Synthetic Methods}

May 4/5, 1992, Interlaken, Switzerland

Chairman: Prof. Rolf Scheffold, University of Bern

Topics in Carbanion Chemistry

Topics in Carbohydrate Chemistry

The detailed programme will be available in Dezember 1991:

Secretary's Office for Symposia

c/o Institute of Organic Chemistry University of Bern

Freiestrasse 3

CH-3012 Bern

Tel. 0316543 11, Fax 031654499

\section{Vorträge}

Polymer-Gruppe der Schweiz

Groupe Suisse des Polymères

Gruppo Svizzero dei Polimeri

29. November 1991 'Polymers for High Technology'

(Réunion Annuelle/Jahrestagung der Polymer Gruppe der Schweiz)

Anmeldung und nähere Auskünfte

Frau S. Read

Sekretariat PGS

Institut für Polymere, ETH-Zentrum

Universitätstrasse 6

CH-8092 Zürich

Tel.: 012563058

30. November $1991 \quad$ Special Polymer Colloquium

'Structure, Deformation and Fracture of Polymers'

Anmeldung und nähere Auskünfte

Mme A. Marciano

EPFL-MX-G

Laboratoire de Technologie des Composites et Polymères

CH-1015 Lausanne

Tél.: 0216934285

\section{Chemische Gesellschaft Fribourg}

Die Vorträge finden jeweils im grossen Hörsaal der Chemischen Institute der Universität Fribourg (Pérolles) statt.

\section{November 199}

17.15 Uhr

19. November 1991

17.15 Uhr
Prof. Dr. P. Müller

Université de Genève

'Chemistry of Cyclopropenes and Cycloproparenes - Synthetic and Mechanistic Studies on Strain and Aromaticity'

Prof. Dr. H. Berke

Universität Zürich

'How to Make Transition Metal Hydrogen Bonds More Reactive - a Conceptual Approach'

\section{Synopsis}

\section{Nomenclature and terminology of graphite intercalation} compounds

Covalent graphite compounds, i.e. graphite fluoride and graphite oxide, should be distinguished from graphite intercalation compounds in which layers of the intercalated substance are inserted between planar carbon sheets of the graphite structure with concomitant charge transfer. Particular to graphite inter- calation compounds is their tendency to form periodically stacked highstage compounds in which only a fraction of the interlayer spaces of the graphite host lattice is filled with intercalated layers. The stage number is defined by the ratio of the total number of interlayer spaces to the number of filled interlayer spaces. 
Schweizerischer Chemiker-Verband

Schweizerische Chemische Gesellschaft

Association Suisse des Chimistes

Société Suisse de Chimie

Swiss Association of Chemists

Swiss Chemical Society

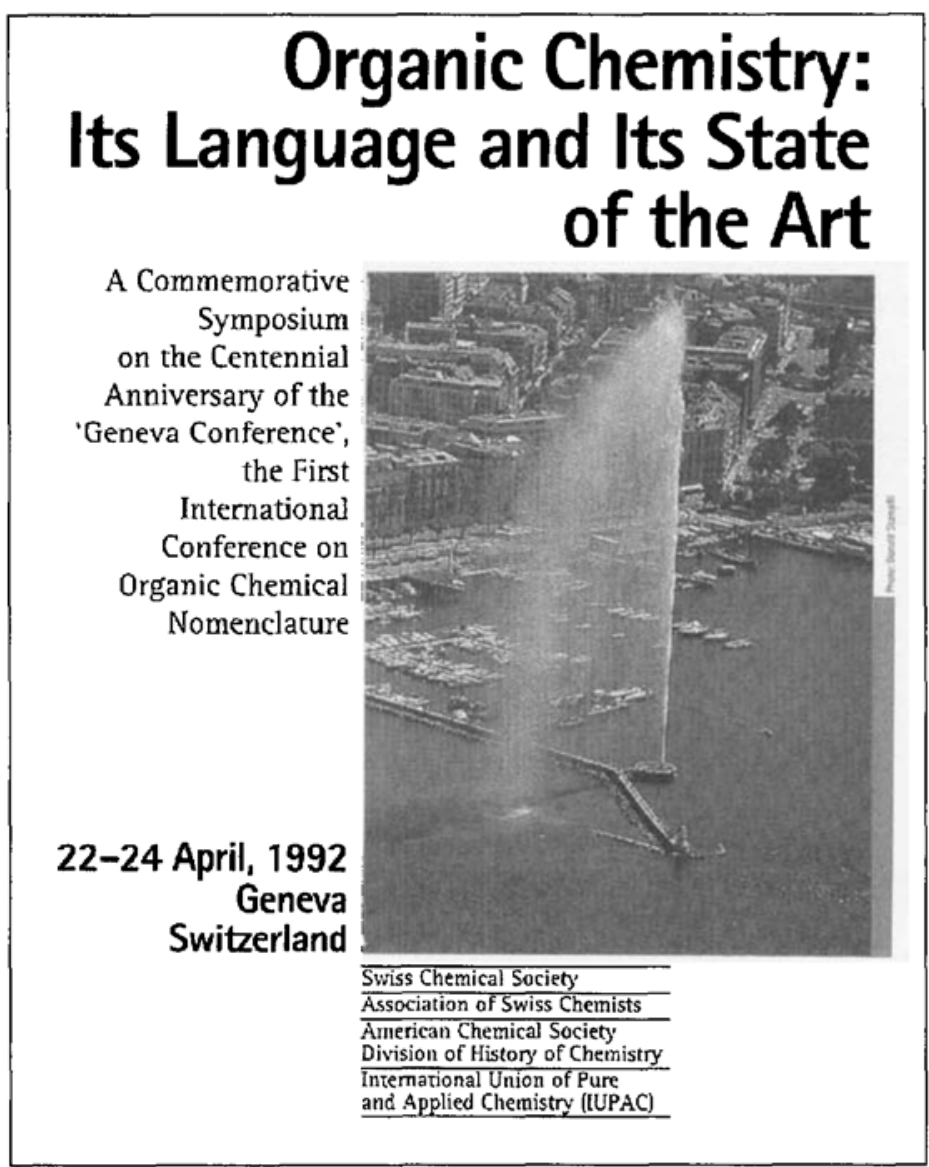

For further information, contact the Conference Chairman:

Dr. M. Volkan Kisakürek

Editor, Helvetica Chimica Acta

Postfach 313

CH-4010 Basel, Switzerland

\section{Schweizerischer Chemiker-Verband \\ Schweizerische Chemische Gesellschaft \\ Association Suisse des Chimistes \\ Société Suisse de Chimie \\ Swiss Association of Chemists \\ Swiss Chemical Society}

Preannouncement

6th International Seminar on

\section{Modern Synthetic Methods}

May 4/5, 1992, Interlaken, Switzerland

Chairman: Prof. Rolf Scheffold, University of Bern

Topics in Carbanion Chemistry

Topics in Carbohydrate Chemistry

The detailed programme will be available in Dezember 1991:

Secretary's Office for Symposia

c/o Institute of Organic Chemistry University of Bern

Freiestrasse 3

CH-3012 Bern

Tel. 0316543 11, Fax 031654499

\section{Vorträge}

Polymer-Gruppe der Schweiz

Groupe Suisse des Polymères

Gruppo Svizzero dei Polimeri

29. November 1991 'Polymers for High Technology'

(Réunion Annuelle/Jahrestagung der Polymer Gruppe der Schweiz)

Anmeldung und nähere Auskünfte

Frau S. Read

Sekretariat PGS

Institut für Polymere, ETH-Zentrum

Universitätstrasse 6

CH-8092 Zürich

Tel.: 012563058

30. November $1991 \quad$ Special Polymer Colloquium

'Structure, Deformation and Fracture of Polymers'

Anmeldung und nähere Auskünfte

Mme A. Marciano

EPFL-MX-G

Laboratoire de Technologie des Composites et Polymères

CH-1015 Lausanne

Tél.: 0216934285

\section{Chemische Gesellschaft Fribourg}

Die Vorträge finden jeweils im grossen Hörsaal der Chemischen Institute der Universität Fribourg (Pérolles) statt.

\section{November 199}

17.15 Uhr

19. November 1991

17.15 Uhr
Prof. Dr. P. Müller

Université de Genève

'Chemistry of Cyclopropenes and Cycloproparenes - Synthetic and Mechanistic Studies on Strain and Aromaticity'

Prof. Dr. H. Berke

Universität Zürich

'How to Make Transition Metal Hydrogen Bonds More Reactive - a Conceptual Approach'

\section{Synopsis}

\section{Nomenclature and terminology of graphite intercalation} compounds

Covalent graphite compounds, i.e. graphite fluoride and graphite oxide, should be distinguished from graphite intercalation compounds in which layers of the intercalated substance are inserted between planar carbon sheets of the graphite structure with concomitant charge transfer. Particular to graphite inter- calation compounds is their tendency to form periodically stacked highstage compounds in which only a fraction of the interlayer spaces of the graphite host lattice is filled with intercalated layers. The stage number is defined by the ratio of the total number of interlayer spaces to the number of filled interlayer spaces. 
Donor and acceptor compounds are differentiated by the direction of the electron transfer to or from the carbon layers, respectively. In naming a graphite intercalation compound, the intercalated element or compound precedes the word graphite, whilst the electropositive constituent is written first in the formula. The stage number is added in parentheses to the name or formula. Often, the space between intercalated ions is filled with solvent molecules; in this case the name or formula of the solvent compound is inserted after that of the electropositive constituent, otherwise it is added after that of the intercalated species. Graphite intercalation compounds are non-stoichiometric; this fact should be taken into account in their formulation. Binary (ternary, etc.) intercalation compounds contain one (two, etc.) chemical species in addition to graphite; free acids and their anions are taken as one chemical species.

In bi-intercalation compounds two different chemical species are inserted in separate interlayer spaces. Rules for structural notation follow those used in the description of polytypes of metal dichalcogenides. Suggestions are presented for the symbols to be used for interlayer spacings, thicknesses of intercalated layers, etc.

Comments on the document are welcome and should be sent by 31 August 1992 to: Dr. H.P. Boehm, Institute für Anorganische Chemie der Universität, Meiserstrabe 1, DMünchen 2.

\section{Nomenclature for chromatography}

The Commission on Analytical Nomenclature of IUPAC has been active for a long time in establishing nomenclatures for chromatography. After proposing suitable nomenclatures for gas chromatography and ion exchange the Commission developed a unified nomenclature for chromatography.

Parallel to these activities other standardization bodies and scientists have also dealt with nomenclatures on gas chromatography, liquid chromatography, exclusion chromatography, and planar chromatography.

The original activities of the IUPAC Commission on Analytical Nomenclature aimed to create a unified nomenclature applicable to all forms of chromatography took place over 10 years ago. Since that time the chromatography techniques advanced significantly. Based on these developments it was decided to prepare a new, up-to-date universal chromatography nomenclature, which also considers the recommendations incorporated in the various other nomenclatures developed since the original work of IUPAC.
The present nomenclature was prepared for the Commission by Dr. L.S. Ettre. It considers all the previous nomenclatures referenced above as well as the three publications dealing with these nomenclatures.

The present nomenclature deals with all chromatographic terms and definitions used in the major chromatographic techniques such as gas, liquid, and supercritical-fluid chromatography, column and planar chromatography, partition, adsorption, ion-exchange and exclusion chromatography. However, it does not include terms related to the results calculated from chromatography date such as e.g. the various molecular weight terms computed from the primary data obtained by exclusion chromatography.

Comments on the document are welcome and should be sent by 30 June 1992 to: Prof. C.A. Cramers, Eindhoven University of Technology, Lab. Instrumental Analysis, Dept. of Chemistry NL-5600 MB Eindhoven, The Netherlands. rücksichtigen (Prävention)

- bestehende Umweltprobleme zu erkennen, zu bewerten und die richtigen Massnahmen interdisziplinär zu veranlassen (Intervention)

Geplant ist ein praxisorentiertes, interdisziplinäres Studium, das Gelegenheit zu praktischen Erfahrungen bietet. Die Ausbildungsinhalte gliedern sich in die Stufen "Grundlagen», «Anwendungen» und «Synthesen». Die Fächerkombination beinhaltet voraussichtlich die Schwerpunkte wie Umweltchemie und -Analytik, Ökologie und Ökotoxikologie, Umweltrecht und Ökonomie etc. Ergänzend sollen Kurse in Informatik, Projektmanagement $e t c$. angeboten werden. Auf den Stufen «Anwendungen» und «Synthesen» werden diese Grundlagen auf konkrete Umweltbereiche
(Gewässerschutz, Lärmschutz, Lufthygiene etc.) und Projekte (Umweltverträglichkeitsprüfungen, betrieblichen Umweltschutz, Abfall, «Ökobilanzen», etc.) angewendet. Das NDS-U ist vollzeitlich (nicht berufsbegleitend) und dauert $2 \mathrm{Se}$ mester.

Für den Aufbau des NDS-U wurde eine begleitende Arbeitsgruppe gebildet, der Fachleute aus der Industrie, der Forschung, aus Ingenieurbüros und Umweltfachstellen der Behörde angehören. Damit wird sichergestellt, dass die heutigen Anforderungen an den Umweltingenieur und die Umweltingenieurin gleichzeitig aus der Situation möglicher zukünftiger Arbeitgeber/-innen und aus der Sicht der Wissenschaft definiert und in Lehrinhalte umgesetzt werden.

\section{European Federation for Medicinal Chemistry}

\section{Announcement}

The European Federation for Medicinal Chemistry (EFMC) announces the

W.Th. Nauta Award for Pharmacochemistry.

The prize will honour the memory of Prof. Dr. Wijbe Nauta whose activities have been very important for the advancement of medicinal chemistry in general and for the development of international organization structures for this discipline.

The W.Th. Nauta Award wil acknowledge results of research in the field of medicinal chemistry obtained by a scientist from one of the countries of the EFMC sphere or research that has been carried out in one of these countries; the Award may also be used to acknowledge any other activities which have conributed to the advancement of medicinal chemistry and/or to the cooperation between countries in this field.
The scientist whose work and/or activities complies with the description given above may qualify for the Award.

The Award will be given for the first time in 1992 and subsequently every second year. The selection of the recipient is the responsibility of the Managment Committee of the EFMC which will nominate a special jury for this purpose. The recipient will receive a diploma and Dfl. 15,000 .

Nominations for the Award are expected no later than March 1, 1992, at the Secretariat of the W.Th. Nauta Award, c/o Prof. Dr. R.F. Rekker, Department of Pharmacochemistry, Vrije Universiteit, De Boelelaan 1083, NL-1081 HV Amsterdam, The Netherlands; tel.: 020-548 57 26; fax: 020-646 1479 . The proposals should include a short curriculum vitae with a list of publications and indicate the reasons for which the candidate qualifies for the Award.

\section{Ingenieurschule beider Basel (HTL)}

\section{Nachdiplomstudium Umweltschutz an der} Ingenieurschule beider Basel

Ab Herbst 1992 wird an der Ingenieurschule beider Basel, Muttenz, neu ein Nachdiplomstudium Umwelt (NDS-U) angeboten. Für den Aufbau des NDS-U wurden vom Technikumsrat Dr. Heinz Leuenherger, Solothurn, und Dr. Thomas Heim, Olten, als hauptamtliche Dozenten mit je 50\% Pensum gewählt.
Das neue Ausbildungszentrum wendet sich an Ingenieur/-innen und Naturwissenschafter/-innen, die in Ämtern, Industriebetrieben und Ingenieurunternehmungen Umweltfragen bearbeiten. Absolventen/innen des NDS-U sollen fähig sein - umweltbezogene Anforderungen bereits bei der Planung, Projektierung und Produktion zu be-

\section{Ehrungen \\ Die Gesellschaft Deutscher Chemiker verlieh in ihrer Festsitzung anlässlich der 23. GDCh-Hauptversammlung in München am 9. September 1991 \\ Herrn Professor Dr. Wolfgang Oppolzer, Département de Chimie Organique, \\ Université de Genève, die Otto-Wallach-Plakette}

in Anerkennung seiner Pionierleistungen auf dem Gebiet innovativer Synthesemethoden. 
Donor and acceptor compounds are differentiated by the direction of the electron transfer to or from the carbon layers, respectively. In naming a graphite intercalation compound, the intercalated element or compound precedes the word graphite, whilst the electropositive constituent is written first in the formula. The stage number is added in parentheses to the name or formula. Often, the space between intercalated ions is filled with solvent molecules; in this case the name or formula of the solvent compound is inserted after that of the electropositive constituent, otherwise it is added after that of the intercalated species. Graphite intercalation compounds are non-stoichiometric; this fact should be taken into account in their formulation. Binary (ternary, etc.) intercalation compounds contain one (two, etc.) chemical species in addition to graphite; free acids and their anions are taken as one chemical species.

In bi-intercalation compounds two different chemical species are inserted in separate interlayer spaces. Rules for structural notation follow those used in the description of polytypes of metal dichalcogenides. Suggestions are presented for the symbols to be used for interlayer spacings, thicknesses of intercalated layers, etc.

Comments on the document are welcome and should be sent by 31 August 1992 to: Dr. H.P. Boehm, Institute für Anorganische Chemie der Universität, Meiserstrabe 1, DMünchen 2.

\section{Nomenclature for chromatography}

The Commission on Analytical Nomenclature of IUPAC has been active for a long time in establishing nomenclatures for chromatography. After proposing suitable nomenclatures for gas chromatography and ion exchange the Commission developed a unified nomenclature for chromatography.

Parallel to these activities other standardization bodies and scientists have also dealt with nomenclatures on gas chromatography, liquid chromatography, exclusion chromatography, and planar chromatography.

The original activities of the IUPAC Commission on Analytical Nomenclature aimed to create a unified nomenclature applicable to all forms of chromatography took place over 10 years ago. Since that time the chromatography techniques advanced significantly. Based on these developments it was decided to prepare a new, up-to-date universal chromatography nomenclature, which also considers the recommendations incorporated in the various other nomenclatures developed since the original work of IUPAC.
The present nomenclature was prepared for the Commission by Dr. L.S. Ettre. It considers all the previous nomenclatures referenced above as well as the three publications dealing with these nomenclatures.

The present nomenclature deals with all chromatographic terms and definitions used in the major chromatographic techniques such as gas, liquid, and supercritical-fluid chromatography, column and planar chromatography, partition, adsorption, ion-exchange and exclusion chromatography. However, it does not include terms related to the results calculated from chromatography date such as e.g. the various molecular weight terms computed from the primary data obtained by exclusion chromatography.

Comments on the document are welcome and should be sent by 30 June 1992 to: Prof. C.A. Cramers, Eindhoven University of Technology, Lab. Instrumental Analysis, Dept. of Chemistry NL-5600 MB Eindhoven, The Netherlands. rücksichtigen (Prävention)

- bestehende Umweltprobleme zu erkennen, zu bewerten und die richtigen Massnahmen interdisziplinär zu veranlassen (Intervention)

Geplant ist ein praxisorentiertes, interdisziplinäres Studium, das Gelegenheit zu praktischen Erfahrungen bietet. Die Ausbildungsinhalte gliedern sich in die Stufen "Grundlagen», «Anwendungen» und «Synthesen». Die Fächerkombination beinhaltet voraussichtlich die Schwerpunkte wie Umweltchemie und -Analytik, Ökologie und Ökotoxikologie, Umweltrecht und Ökonomie etc. Ergänzend sollen Kurse in Informatik, Projektmanagement $e t c$. angeboten werden. Auf den Stufen «Anwendungen» und «Synthesen» werden diese Grundlagen auf konkrete Umweltbereiche
(Gewässerschutz, Lärmschutz, Lufthygiene etc.) und Projekte (Umweltverträglichkeitsprüfungen, betrieblichen Umweltschutz, Abfall, «Ökobilanzen», etc.) angewendet. Das NDS-U ist vollzeitlich (nicht berufsbegleitend) und dauert $2 \mathrm{Se}$ mester.

Für den Aufbau des NDS-U wurde eine begleitende Arbeitsgruppe gebildet, der Fachleute aus der Industrie, der Forschung, aus Ingenieurbüros und Umweltfachstellen der Behörde angehören. Damit wird sichergestellt, dass die heutigen Anforderungen an den Umweltingenieur und die Umweltingenieurin gleichzeitig aus der Situation möglicher zukünftiger Arbeitgeber/-innen und aus der Sicht der Wissenschaft definiert und in Lehrinhalte umgesetzt werden.

\section{European Federation for Medicinal Chemistry}

\section{Announcement}

The European Federation for Medicinal Chemistry (EFMC) announces the

W.Th. Nauta Award for Pharmacochemistry.

The prize will honour the memory of Prof. Dr. Wijbe Nauta whose activities have been very important for the advancement of medicinal chemistry in general and for the development of international organization structures for this discipline.

The W.Th. Nauta Award wil acknowledge results of research in the field of medicinal chemistry obtained by a scientist from one of the countries of the EFMC sphere or research that has been carried out in one of these countries; the Award may also be used to acknowledge any other activities which have conributed to the advancement of medicinal chemistry and/or to the cooperation between countries in this field.
The scientist whose work and/or activities complies with the description given above may qualify for the Award.

The Award will be given for the first time in 1992 and subsequently every second year. The selection of the recipient is the responsibility of the Managment Committee of the EFMC which will nominate a special jury for this purpose. The recipient will receive a diploma and Dfl. 15,000 .

Nominations for the Award are expected no later than March 1, 1992, at the Secretariat of the W.Th. Nauta Award, c/o Prof. Dr. R.F. Rekker, Department of Pharmacochemistry, Vrije Universiteit, De Boelelaan 1083, NL-1081 HV Amsterdam, The Netherlands; tel.: 020-548 57 26; fax: 020-646 1479 . The proposals should include a short curriculum vitae with a list of publications and indicate the reasons for which the candidate qualifies for the Award.

\section{Ingenieurschule beider Basel (HTL)}

\section{Nachdiplomstudium Umweltschutz an der} Ingenieurschule beider Basel

Ab Herbst 1992 wird an der Ingenieurschule beider Basel, Muttenz, neu ein Nachdiplomstudium Umwelt (NDS-U) angeboten. Für den Aufbau des NDS-U wurden vom Technikumsrat Dr. Heinz Leuenherger, Solothurn, und Dr. Thomas Heim, Olten, als hauptamtliche Dozenten mit je 50\% Pensum gewählt.
Das neue Ausbildungszentrum wendet sich an Ingenieur/-innen und Naturwissenschafter/-innen, die in Ämtern, Industriebetrieben und Ingenieurunternehmungen Umweltfragen bearbeiten. Absolventen/innen des NDS-U sollen fähig sein - umweltbezogene Anforderungen bereits bei der Planung, Projektierung und Produktion zu be-

\section{Ehrungen \\ Die Gesellschaft Deutscher Chemiker verlieh in ihrer Festsitzung anlässlich der 23. GDCh-Hauptversammlung in München am 9. September 1991 \\ Herrn Professor Dr. Wolfgang Oppolzer, Département de Chimie Organique, \\ Université de Genève, die Otto-Wallach-Plakette}

in Anerkennung seiner Pionierleistungen auf dem Gebiet innovativer Synthesemethoden. 
Donor and acceptor compounds are differentiated by the direction of the electron transfer to or from the carbon layers, respectively. In naming a graphite intercalation compound, the intercalated element or compound precedes the word graphite, whilst the electropositive constituent is written first in the formula. The stage number is added in parentheses to the name or formula. Often, the space between intercalated ions is filled with solvent molecules; in this case the name or formula of the solvent compound is inserted after that of the electropositive constituent, otherwise it is added after that of the intercalated species. Graphite intercalation compounds are non-stoichiometric; this fact should be taken into account in their formulation. Binary (ternary, etc.) intercalation compounds contain one (two, etc.) chemical species in addition to graphite; free acids and their anions are taken as one chemical species.

In bi-intercalation compounds two different chemical species are inserted in separate interlayer spaces. Rules for structural notation follow those used in the description of polytypes of metal dichalcogenides. Suggestions are presented for the symbols to be used for interlayer spacings, thicknesses of intercalated layers, etc.

Comments on the document are welcome and should be sent by 31 August 1992 to: Dr. H.P. Boehm, Institute für Anorganische Chemie der Universität, Meiserstrabe 1, DMünchen 2.

\section{Nomenclature for chromatography}

The Commission on Analytical Nomenclature of IUPAC has been active for a long time in establishing nomenclatures for chromatography. After proposing suitable nomenclatures for gas chromatography and ion exchange the Commission developed a unified nomenclature for chromatography.

Parallel to these activities other standardization bodies and scientists have also dealt with nomenclatures on gas chromatography, liquid chromatography, exclusion chromatography, and planar chromatography.

The original activities of the IUPAC Commission on Analytical Nomenclature aimed to create a unified nomenclature applicable to all forms of chromatography took place over 10 years ago. Since that time the chromatography techniques advanced significantly. Based on these developments it was decided to prepare a new, up-to-date universal chromatography nomenclature, which also considers the recommendations incorporated in the various other nomenclatures developed since the original work of IUPAC.
The present nomenclature was prepared for the Commission by Dr. L.S. Ettre. It considers all the previous nomenclatures referenced above as well as the three publications dealing with these nomenclatures.

The present nomenclature deals with all chromatographic terms and definitions used in the major chromatographic techniques such as gas, liquid, and supercritical-fluid chromatography, column and planar chromatography, partition, adsorption, ion-exchange and exclusion chromatography. However, it does not include terms related to the results calculated from chromatography date such as e.g. the various molecular weight terms computed from the primary data obtained by exclusion chromatography.

Comments on the document are welcome and should be sent by 30 June 1992 to: Prof. C.A. Cramers, Eindhoven University of Technology, Lab. Instrumental Analysis, Dept. of Chemistry NL-5600 MB Eindhoven, The Netherlands. rücksichtigen (Prävention)

- bestehende Umweltprobleme zu erkennen, zu bewerten und die richtigen Massnahmen interdisziplinär zu veranlassen (Intervention)

Geplant ist ein praxisorentiertes, interdisziplinäres Studium, das Gelegenheit zu praktischen Erfahrungen bietet. Die Ausbildungsinhalte gliedern sich in die Stufen "Grundlagen», «Anwendungen» und «Synthesen». Die Fächerkombination beinhaltet voraussichtlich die Schwerpunkte wie Umweltchemie und -Analytik, Ökologie und Ökotoxikologie, Umweltrecht und Ökonomie etc. Ergänzend sollen Kurse in Informatik, Projektmanagement $e t c$. angeboten werden. Auf den Stufen «Anwendungen» und «Synthesen» werden diese Grundlagen auf konkrete Umweltbereiche
(Gewässerschutz, Lärmschutz, Lufthygiene etc.) und Projekte (Umweltverträglichkeitsprüfungen, betrieblichen Umweltschutz, Abfall, «Ökobilanzen», etc.) angewendet. Das NDS-U ist vollzeitlich (nicht berufsbegleitend) und dauert $2 \mathrm{Se}$ mester.

Für den Aufbau des NDS-U wurde eine begleitende Arbeitsgruppe gebildet, der Fachleute aus der Industrie, der Forschung, aus Ingenieurbüros und Umweltfachstellen der Behörde angehören. Damit wird sichergestellt, dass die heutigen Anforderungen an den Umweltingenieur und die Umweltingenieurin gleichzeitig aus der Situation möglicher zukünftiger Arbeitgeber/-innen und aus der Sicht der Wissenschaft definiert und in Lehrinhalte umgesetzt werden.

\section{European Federation for Medicinal Chemistry}

\section{Announcement}

The European Federation for Medicinal Chemistry (EFMC) announces the

W.Th. Nauta Award for Pharmacochemistry.

The prize will honour the memory of Prof. Dr. Wijbe Nauta whose activities have been very important for the advancement of medicinal chemistry in general and for the development of international organization structures for this discipline.

The W.Th. Nauta Award wil acknowledge results of research in the field of medicinal chemistry obtained by a scientist from one of the countries of the EFMC sphere or research that has been carried out in one of these countries; the Award may also be used to acknowledge any other activities which have conributed to the advancement of medicinal chemistry and/or to the cooperation between countries in this field.
The scientist whose work and/or activities complies with the description given above may qualify for the Award.

The Award will be given for the first time in 1992 and subsequently every second year. The selection of the recipient is the responsibility of the Managment Committee of the EFMC which will nominate a special jury for this purpose. The recipient will receive a diploma and Dfl. 15,000 .

Nominations for the Award are expected no later than March 1, 1992, at the Secretariat of the W.Th. Nauta Award, c/o Prof. Dr. R.F. Rekker, Department of Pharmacochemistry, Vrije Universiteit, De Boelelaan 1083, NL-1081 HV Amsterdam, The Netherlands; tel.: 020-548 57 26; fax: 020-646 1479 . The proposals should include a short curriculum vitae with a list of publications and indicate the reasons for which the candidate qualifies for the Award.

\section{Ingenieurschule beider Basel (HTL)}

\section{Nachdiplomstudium Umweltschutz an der} Ingenieurschule beider Basel

Ab Herbst 1992 wird an der Ingenieurschule beider Basel, Muttenz, neu ein Nachdiplomstudium Umwelt (NDS-U) angeboten. Für den Aufbau des NDS-U wurden vom Technikumsrat Dr. Heinz Leuenherger, Solothurn, und Dr. Thomas Heim, Olten, als hauptamtliche Dozenten mit je 50\% Pensum gewählt.
Das neue Ausbildungszentrum wendet sich an Ingenieur/-innen und Naturwissenschafter/-innen, die in Ämtern, Industriebetrieben und Ingenieurunternehmungen Umweltfragen bearbeiten. Absolventen/innen des NDS-U sollen fähig sein - umweltbezogene Anforderungen bereits bei der Planung, Projektierung und Produktion zu be-

\section{Ehrungen \\ Die Gesellschaft Deutscher Chemiker verlieh in ihrer Festsitzung anlässlich der 23. GDCh-Hauptversammlung in München am 9. September 1991 \\ Herrn Professor Dr. Wolfgang Oppolzer, Département de Chimie Organique, \\ Université de Genève, die Otto-Wallach-Plakette}

in Anerkennung seiner Pionierleistungen auf dem Gebiet innovativer Synthesemethoden. 
Donor and acceptor compounds are differentiated by the direction of the electron transfer to or from the carbon layers, respectively. In naming a graphite intercalation compound, the intercalated element or compound precedes the word graphite, whilst the electropositive constituent is written first in the formula. The stage number is added in parentheses to the name or formula. Often, the space between intercalated ions is filled with solvent molecules; in this case the name or formula of the solvent compound is inserted after that of the electropositive constituent, otherwise it is added after that of the intercalated species. Graphite intercalation compounds are non-stoichiometric; this fact should be taken into account in their formulation. Binary (ternary, etc.) intercalation compounds contain one (two, etc.) chemical species in addition to graphite; free acids and their anions are taken as one chemical species.

In bi-intercalation compounds two different chemical species are inserted in separate interlayer spaces. Rules for structural notation follow those used in the description of polytypes of metal dichalcogenides. Suggestions are presented for the symbols to be used for interlayer spacings, thicknesses of intercalated layers, etc.

Comments on the document are welcome and should be sent by 31 August 1992 to: Dr. H.P. Boehm, Institute für Anorganische Chemie der Universität, Meiserstrabe 1, DMünchen 2.

\section{Nomenclature for chromatography}

The Commission on Analytical Nomenclature of IUPAC has been active for a long time in establishing nomenclatures for chromatography. After proposing suitable nomenclatures for gas chromatography and ion exchange the Commission developed a unified nomenclature for chromatography.

Parallel to these activities other standardization bodies and scientists have also dealt with nomenclatures on gas chromatography, liquid chromatography, exclusion chromatography, and planar chromatography.

The original activities of the IUPAC Commission on Analytical Nomenclature aimed to create a unified nomenclature applicable to all forms of chromatography took place over 10 years ago. Since that time the chromatography techniques advanced significantly. Based on these developments it was decided to prepare a new, up-to-date universal chromatography nomenclature, which also considers the recommendations incorporated in the various other nomenclatures developed since the original work of IUPAC.
The present nomenclature was prepared for the Commission by Dr. L.S. Ettre. It considers all the previous nomenclatures referenced above as well as the three publications dealing with these nomenclatures.

The present nomenclature deals with all chromatographic terms and definitions used in the major chromatographic techniques such as gas, liquid, and supercritical-fluid chromatography, column and planar chromatography, partition, adsorption, ion-exchange and exclusion chromatography. However, it does not include terms related to the results calculated from chromatography date such as e.g. the various molecular weight terms computed from the primary data obtained by exclusion chromatography.

Comments on the document are welcome and should be sent by 30 June 1992 to: Prof. C.A. Cramers, Eindhoven University of Technology, Lab. Instrumental Analysis, Dept. of Chemistry NL-5600 MB Eindhoven, The Netherlands. rücksichtigen (Prävention)

- bestehende Umweltprobleme zu erkennen, zu bewerten und die richtigen Massnahmen interdisziplinär zu veranlassen (Intervention)

Geplant ist ein praxisorentiertes, interdisziplinäres Studium, das Gelegenheit zu praktischen Erfahrungen bietet. Die Ausbildungsinhalte gliedern sich in die Stufen "Grundlagen», «Anwendungen» und «Synthesen». Die Fächerkombination beinhaltet voraussichtlich die Schwerpunkte wie Umweltchemie und -Analytik, Ökologie und Ökotoxikologie, Umweltrecht und Ökonomie etc. Ergänzend sollen Kurse in Informatik, Projektmanagement $e t c$. angeboten werden. Auf den Stufen «Anwendungen» und «Synthesen» werden diese Grundlagen auf konkrete Umweltbereiche
(Gewässerschutz, Lärmschutz, Lufthygiene etc.) und Projekte (Umweltverträglichkeitsprüfungen, betrieblichen Umweltschutz, Abfall, «Ökobilanzen», etc.) angewendet. Das NDS-U ist vollzeitlich (nicht berufsbegleitend) und dauert $2 \mathrm{Se}$ mester.

Für den Aufbau des NDS-U wurde eine begleitende Arbeitsgruppe gebildet, der Fachleute aus der Industrie, der Forschung, aus Ingenieurbüros und Umweltfachstellen der Behörde angehören. Damit wird sichergestellt, dass die heutigen Anforderungen an den Umweltingenieur und die Umweltingenieurin gleichzeitig aus der Situation möglicher zukünftiger Arbeitgeber/-innen und aus der Sicht der Wissenschaft definiert und in Lehrinhalte umgesetzt werden.

\section{European Federation for Medicinal Chemistry}

\section{Announcement}

The European Federation for Medicinal Chemistry (EFMC) announces the

W.Th. Nauta Award for Pharmacochemistry.

The prize will honour the memory of Prof. Dr. Wijbe Nauta whose activities have been very important for the advancement of medicinal chemistry in general and for the development of international organization structures for this discipline.

The W.Th. Nauta Award wil acknowledge results of research in the field of medicinal chemistry obtained by a scientist from one of the countries of the EFMC sphere or research that has been carried out in one of these countries; the Award may also be used to acknowledge any other activities which have conributed to the advancement of medicinal chemistry and/or to the cooperation between countries in this field.
The scientist whose work and/or activities complies with the description given above may qualify for the Award.

The Award will be given for the first time in 1992 and subsequently every second year. The selection of the recipient is the responsibility of the Managment Committee of the EFMC which will nominate a special jury for this purpose. The recipient will receive a diploma and Dfl. 15,000 .

Nominations for the Award are expected no later than March 1, 1992, at the Secretariat of the W.Th. Nauta Award, c/o Prof. Dr. R.F. Rekker, Department of Pharmacochemistry, Vrije Universiteit, De Boelelaan 1083, NL-1081 HV Amsterdam, The Netherlands; tel.: 020-548 57 26; fax: 020-646 1479 . The proposals should include a short curriculum vitae with a list of publications and indicate the reasons for which the candidate qualifies for the Award.

\section{Ingenieurschule beider Basel (HTL)}

\section{Nachdiplomstudium Umweltschutz an der} Ingenieurschule beider Basel

Ab Herbst 1992 wird an der Ingenieurschule beider Basel, Muttenz, neu ein Nachdiplomstudium Umwelt (NDS-U) angeboten. Für den Aufbau des NDS-U wurden vom Technikumsrat Dr. Heinz Leuenherger, Solothurn, und Dr. Thomas Heim, Olten, als hauptamtliche Dozenten mit je 50\% Pensum gewählt.
Das neue Ausbildungszentrum wendet sich an Ingenieur/-innen und Naturwissenschafter/-innen, die in Ämtern, Industriebetrieben und Ingenieurunternehmungen Umweltfragen bearbeiten. Absolventen/innen des NDS-U sollen fähig sein - umweltbezogene Anforderungen bereits bei der Planung, Projektierung und Produktion zu be-

\section{Ehrungen \\ Die Gesellschaft Deutscher Chemiker verlieh in ihrer Festsitzung anlässlich der 23. GDCh-Hauptversammlung in München am 9. September 1991 \\ Herrn Professor Dr. Wolfgang Oppolzer, Département de Chimie Organique, \\ Université de Genève, die Otto-Wallach-Plakette}

in Anerkennung seiner Pionierleistungen auf dem Gebiet innovativer Synthesemethoden. 
Donor and acceptor compounds are differentiated by the direction of the electron transfer to or from the carbon layers, respectively. In naming a graphite intercalation compound, the intercalated element or compound precedes the word graphite, whilst the electropositive constituent is written first in the formula. The stage number is added in parentheses to the name or formula. Often, the space between intercalated ions is filled with solvent molecules; in this case the name or formula of the solvent compound is inserted after that of the electropositive constituent, otherwise it is added after that of the intercalated species. Graphite intercalation compounds are non-stoichiometric; this fact should be taken into account in their formulation. Binary (ternary, etc.) intercalation compounds contain one (two, etc.) chemical species in addition to graphite; free acids and their anions are taken as one chemical species.

In bi-intercalation compounds two different chemical species are inserted in separate interlayer spaces. Rules for structural notation follow those used in the description of polytypes of metal dichalcogenides. Suggestions are presented for the symbols to be used for interlayer spacings, thicknesses of intercalated layers, etc.

Comments on the document are welcome and should be sent by 31 August 1992 to: Dr. H.P. Boehm, Institute für Anorganische Chemie der Universität, Meiserstrabe 1, DMünchen 2.

\section{Nomenclature for chromatography}

The Commission on Analytical Nomenclature of IUPAC has been active for a long time in establishing nomenclatures for chromatography. After proposing suitable nomenclatures for gas chromatography and ion exchange the Commission developed a unified nomenclature for chromatography.

Parallel to these activities other standardization bodies and scientists have also dealt with nomenclatures on gas chromatography, liquid chromatography, exclusion chromatography, and planar chromatography.

The original activities of the IUPAC Commission on Analytical Nomenclature aimed to create a unified nomenclature applicable to all forms of chromatography took place over 10 years ago. Since that time the chromatography techniques advanced significantly. Based on these developments it was decided to prepare a new, up-to-date universal chromatography nomenclature, which also considers the recommendations incorporated in the various other nomenclatures developed since the original work of IUPAC.
The present nomenclature was prepared for the Commission by Dr. L.S. Ettre. It considers all the previous nomenclatures referenced above as well as the three publications dealing with these nomenclatures.

The present nomenclature deals with all chromatographic terms and definitions used in the major chromatographic techniques such as gas, liquid, and supercritical-fluid chromatography, column and planar chromatography, partition, adsorption, ion-exchange and exclusion chromatography. However, it does not include terms related to the results calculated from chromatography date such as e.g. the various molecular weight terms computed from the primary data obtained by exclusion chromatography.

Comments on the document are welcome and should be sent by 30 June 1992 to: Prof. C.A. Cramers, Eindhoven University of Technology, Lab. Instrumental Analysis, Dept. of Chemistry NL-5600 MB Eindhoven, The Netherlands. rücksichtigen (Prävention)

- bestehende Umweltprobleme zu erkennen, zu bewerten und die richtigen Massnahmen interdisziplinär zu veranlassen (Intervention)

Geplant ist ein praxisorentiertes, interdisziplinäres Studium, das Gelegenheit zu praktischen Erfahrungen bietet. Die Ausbildungsinhalte gliedern sich in die Stufen "Grundlagen», «Anwendungen» und «Synthesen». Die Fächerkombination beinhaltet voraussichtlich die Schwerpunkte wie Umweltchemie und -Analytik, Ökologie und Ökotoxikologie, Umweltrecht und Ökonomie etc. Ergänzend sollen Kurse in Informatik, Projektmanagement $e t c$. angeboten werden. Auf den Stufen «Anwendungen» und «Synthesen» werden diese Grundlagen auf konkrete Umweltbereiche
(Gewässerschutz, Lärmschutz, Lufthygiene etc.) und Projekte (Umweltverträglichkeitsprüfungen, betrieblichen Umweltschutz, Abfall, «Ökobilanzen», etc.) angewendet. Das NDS-U ist vollzeitlich (nicht berufsbegleitend) und dauert $2 \mathrm{Se}$ mester.

Für den Aufbau des NDS-U wurde eine begleitende Arbeitsgruppe gebildet, der Fachleute aus der Industrie, der Forschung, aus Ingenieurbüros und Umweltfachstellen der Behörde angehören. Damit wird sichergestellt, dass die heutigen Anforderungen an den Umweltingenieur und die Umweltingenieurin gleichzeitig aus der Situation möglicher zukünftiger Arbeitgeber/-innen und aus der Sicht der Wissenschaft definiert und in Lehrinhalte umgesetzt werden.

\section{European Federation for Medicinal Chemistry}

\section{Announcement}

The European Federation for Medicinal Chemistry (EFMC) announces the

W.Th. Nauta Award for Pharmacochemistry.

The prize will honour the memory of Prof. Dr. Wijbe Nauta whose activities have been very important for the advancement of medicinal chemistry in general and for the development of international organization structures for this discipline.

The W.Th. Nauta Award wil acknowledge results of research in the field of medicinal chemistry obtained by a scientist from one of the countries of the EFMC sphere or research that has been carried out in one of these countries; the Award may also be used to acknowledge any other activities which have conributed to the advancement of medicinal chemistry and/or to the cooperation between countries in this field.
The scientist whose work and/or activities complies with the description given above may qualify for the Award.

The Award will be given for the first time in 1992 and subsequently every second year. The selection of the recipient is the responsibility of the Managment Committee of the EFMC which will nominate a special jury for this purpose. The recipient will receive a diploma and Dfl. 15,000 .

Nominations for the Award are expected no later than March 1, 1992, at the Secretariat of the W.Th. Nauta Award, c/o Prof. Dr. R.F. Rekker, Department of Pharmacochemistry, Vrije Universiteit, De Boelelaan 1083, NL-1081 HV Amsterdam, The Netherlands; tel.: 020-548 57 26; fax: 020-646 1479 . The proposals should include a short curriculum vitae with a list of publications and indicate the reasons for which the candidate qualifies for the Award.

\section{Ingenieurschule beider Basel (HTL)}

\section{Nachdiplomstudium Umweltschutz an der} Ingenieurschule beider Basel

Ab Herbst 1992 wird an der Ingenieurschule beider Basel, Muttenz, neu ein Nachdiplomstudium Umwelt (NDS-U) angeboten. Für den Aufbau des NDS-U wurden vom Technikumsrat Dr. Heinz Leuenherger, Solothurn, und Dr. Thomas Heim, Olten, als hauptamtliche Dozenten mit je 50\% Pensum gewählt.
Das neue Ausbildungszentrum wendet sich an Ingenieur/-innen und Naturwissenschafter/-innen, die in Ämtern, Industriebetrieben und Ingenieurunternehmungen Umweltfragen bearbeiten. Absolventen/innen des NDS-U sollen fähig sein - umweltbezogene Anforderungen bereits bei der Planung, Projektierung und Produktion zu be-

\section{Ehrungen \\ Die Gesellschaft Deutscher Chemiker verlieh in ihrer Festsitzung anlässlich der 23. GDCh-Hauptversammlung in München am 9. September 1991 \\ Herrn Professor Dr. Wolfgang Oppolzer, Département de Chimie Organique, \\ Université de Genève, die Otto-Wallach-Plakette}

in Anerkennung seiner Pionierleistungen auf dem Gebiet innovativer Synthesemethoden. 
NW $15-150$

Kompakt-Bauweise

O PVDF - Auskleidung

O Hastelloy - Elektroden

getaktete Gleichfeldtechnik

O digitale Messbereichswahl

$\bigcirc$ freier Messrohr-Querschnitt

volumetrische Durchflussmessung

O bidirektionale Durchflussmessung

O Ex-Schutz (Ex) eis G4

$\bigcirc$ Vorortanzeige
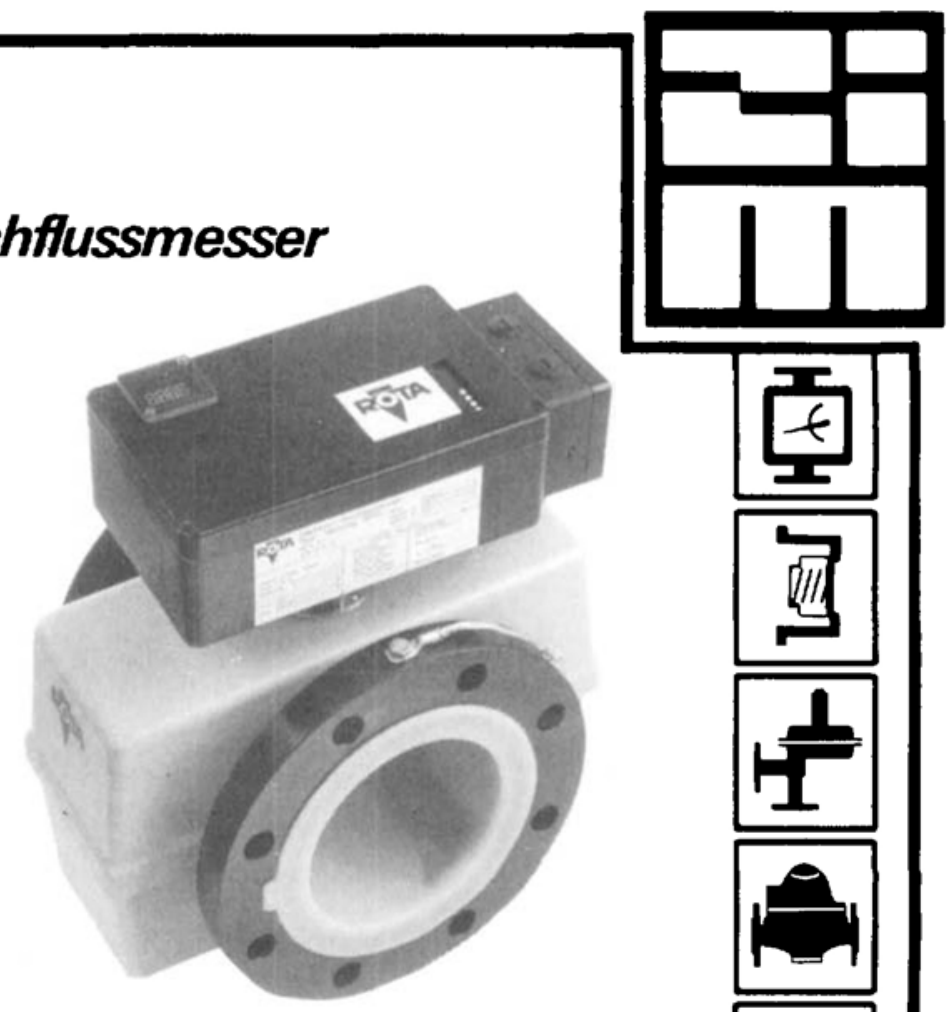

Wir senden Ihnen gerne detaillierte Unterlagen

\section{Der CHIMIA-Leserdienst zu Ihrem Vorteil}

Die Beiträge der Rubrik «CHIMIA-Report» sind mit einer Kennziffer markiert.

Wenn Sie zu einem oder mehreren der auf diese Weise gekennzeichneten Informationsangebote zusätzlich Auskünfte erhalten möchten, empfiehlt sich als einfachster und billigster Weg:

1. Entsprechende Nummer(n) auf dem nebenstehenden Leserdienst-Talon anzeichnen;

2. Absender angeben;

3. Talon an untenstehende Adresse einsenden.

Ihre Anfragen werden sofort an die einzelnen Firmen weitergeleitet, die Ihnen die gewünschten Auskünfte gerne zur Verfügung stellen werden. Wir würden uns freuen, wenn Sie unseren Leserdienst benutzen!

CHIMIA-Leserdienst

Postfach 2027, CH-4001 Basel

Telefon 061 - 2816787

Fax 061 - 2816784

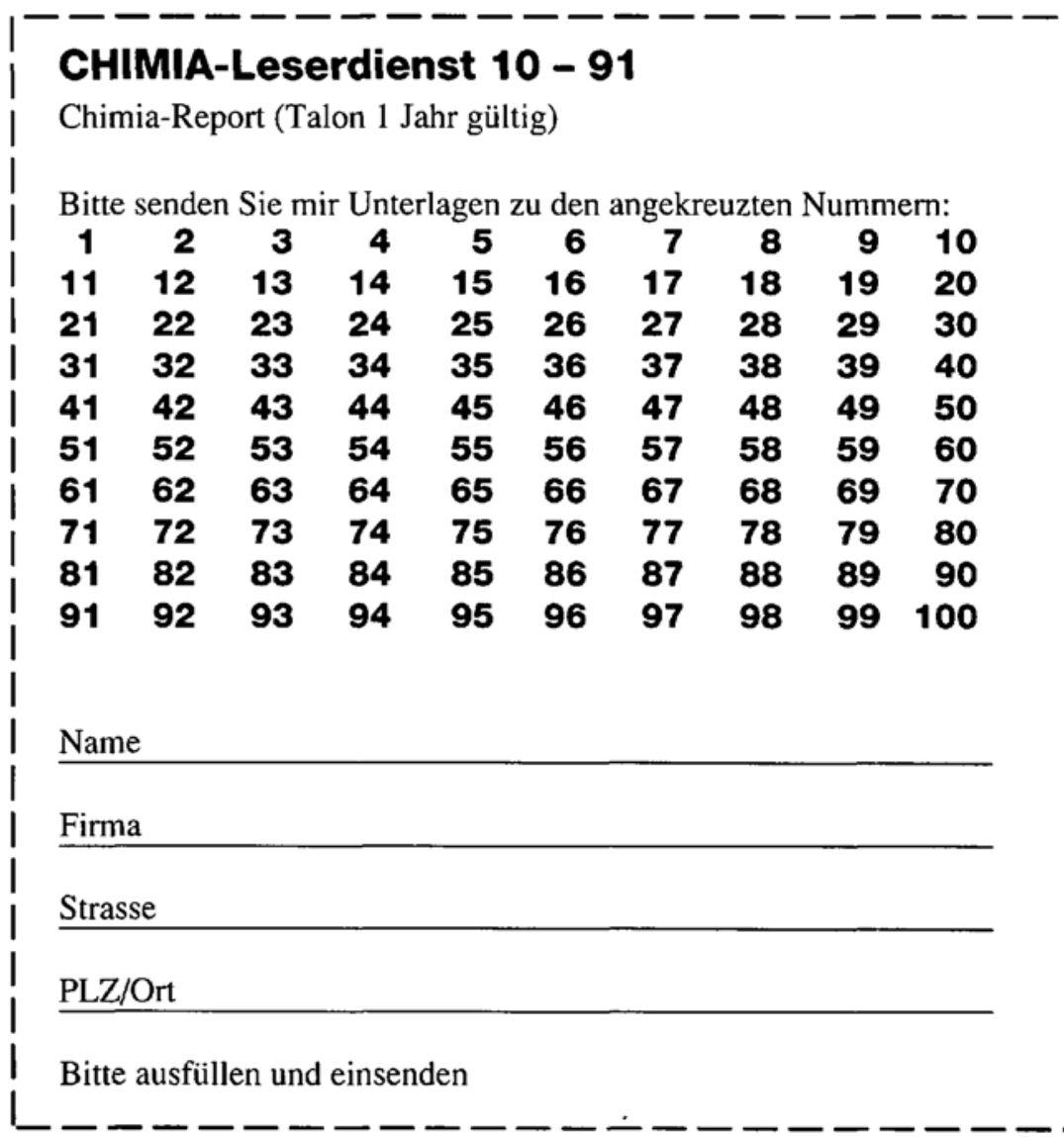

